\title{
Metabotropic Glutamate Receptor 6
}

National Cancer Institute

\section{Source}

National Cancer Institute. Metabotropic Glutamate Receptor 6. NCI Thesaurus. Code C26243.

Metabotropic glutamate receptor 6 ( $877 \mathrm{aa}, \sim 95, \mathrm{kDa}$ ) is encoded by the human GRM6 gene. This protein is involved in both glutamate binding and the regulation of second messenger signaling. 